\title{
ARL Directors: Two Decades of Changes
}

\section{Marcia J. Myers and Paula T. Kaufman}

\begin{abstract}
This study examines a wide range of changes among ARL directors from 1970-1989 on such variables as gender, previous positions held, and volumes in the collections. In 1970, there were no female directors of ARL libraries; in 1989 there were 32 female directors. This increase has changed the demographic characteristics of ARL directors. As a group, female directors are younger, have fewer years of service, earn higher average salaries, and have received higher increases in their libraries' budgets when they assumed their jobs than male directors.
\end{abstract}

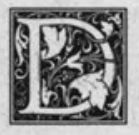

uring the past two decades, higher education has been subject to many stresses and changes. In 1973, Arthur M. McAnally and Robert B. Downs published their classic article on the changing role of the university library director. ${ }^{1}$ McAnally and Downs expressed concern about the recent high turnover rate in this position and predicted that if the trend continued, the average span of service for directors might drop to only 5 or 6 years. As librarians enter the 1990 s, it seems appropriate to reexamine the tenure and other characteristics of directors of large research libraries. Are many directors leaving their positions to retire early or to go into teaching or other fields, as Anne Woodsworth recently suggested? ${ }^{2}$ Have the reasons for leaving the directorship or the age and educational backgrounds of directors changed over the years? What changes, if any, have occurred in the characteristics of library directors in light of the increasing number of females assuming top positions? What, if any, new trends can be predicted for the 1990s?

\section{LITERATURE REVIEW}

There has been a fair amount of research about the characteristics of research library directors during the last half-century. William L. Cohn studied 254 U.S. Association of Research Library (ARL) directors covering the period 1933 to $1973 .{ }^{3}$ Of the 74 ARL libraries in 1973 , $34(46 \%)$ had named a new director in the previous 4 years. Although there had been a large increase in the number of library doctorates awarded, this trend was not reflected among the ARL directors, whose most common highest degree was the M.L.S. In the period 1933 to $1973,54 \%$ of the directors died in office or retired; $14 \%$ went into teaching.

Jerry L. Parsons contrasted the characteristics of directors of U.S. ARL libraries for the years 1958 and $1973 .^{4}$ He found that there was not a trend toward younger directors: the average age in 1953 was 51 years, while the average age in 1973 was 53 years. There were no women

Marcia J. Myers is the Associate Dean of Libraries for Administrative Services and Paula T. Kaufman is the Dean of Libraries at the University of Tennessee, Knoxville, Tennessee 37996. Special appreciation goes to Loretta McCuiston for her assistance with data entry. 
directors in 1953; in 1973, there were 4 female directors. The 1953 group held 26 doctorates; the 1973 group held 25 doctorates. In 1958, the majority of the directors had been promoted from within. In contrast, the majority of the 1973 directors were recruited from other institutions. Parsons also found that the tenure of ARL directors appeared to be developing into a short-term assignment. In 1958 , the average tenure of a director was more than 8 years, with a median of 9 years. In 1973, the average tenure of the directors was less than 8 years with a median of only 5 years.

In a letter to the editor of College $\mathcal{E} R e$ search Libraries Louis Kaplan provided historical data on ARL directors who withdrew from administration before age $65^{5}$ The percentage of those who left administration increased from $10 \%$ to $20 \%$ in the 1926-1942 period to $26 \%$ in $1968-1975$. Kaplan thought the reason that more directors left between 1968-1975 was because of the decline in fiscal support that began to be felt in 1967.

Janice Fennell, noting that librarianship is $84 \%$ female, studied 11 female directors of large academic libraries in 1978 to develop a composite career profile. ${ }^{6}$ She concluded that if a woman becomes director of a large academic library in the United States, she is likely to be middle-aged (an average age of 48), married with no children, and from a middle-class background. The profile indicated that the typical female director possesses no higher than a master's degree; however, she is interested in both formal and informal continuing education. The profile also indicated that the female director has held her current position for less than 10 years and entered the position directly from another administrative position.

Ronald Dale Karr studied directors of 90 U.S. ARL libraries in 1966 and 1981.? He excluded libraries with vacancies, acting directors, or nonlibrarians serving as directors. One of the more notable differences between the directors in the two groups was gender: there was only 1 female library director in 1966 and 12 in 1981. Of the 1966 directors, $15 \%$ lacked the library degree, but by 1981 , every director was a graduate of a certified graduate library program. The proportion of directors with doctorates fell from $44 \%$ in 1966 to $33 \%$ in 1981 . Although the 1981 directors had taken longer to reach their present positions, they were younger (an average of 51.2 years) than the 1966 directors (53.6 years). The 1981 group had served an average of 6.7 years in their current positions, while the 1966 group had served an average of 11.4 years.

William S. Wong and David S. Zubatsky studied the tenure rates of $91 \mathrm{ARL}$ and 80 non-ARL library directors in $1983 .^{8}$ They excluded vacancies and acting directors from the study. Seventy-five of the ARL directors were male and 16 were female. Twenty-two directors of ARL libraries (19 males and 3 females) were promoted from within their institutions to the directorship. Results of the survey support previous findings that the number of individuals holding the doctorate has not increased despite the fact that there has been an increase in the number of individuals holding the doctorate in library science. Thirty-three ARL directors (32 males and 1 female), or $36 \%$ of the 91 respondents, had held their position for 9 or more years. Sixty-seven percent had held their positions for 5 or more years. These findings did not support McAnally and Downs' prediction of short tenures for library directors. Women were more likely than men $(62.5 \%$ versus $46.7 \%)$ to hold their positions for 6 or less years, but this may be attributable to their more recent attainment of such positions as a group.

In 1989, Anne Woodsworth reexamined the McAnally and Downs article. ${ }^{9}$ She indicated that the situation regarding the tenure of library directors has not changed. In the past 3 or 4 years, more than half of the U.S. ARL libraries have seen a change in directors. The turnover predicted by McAnally and Downs seems to have become the norm. Woodsworth perceived that while some of the attrition is normal, human factors contribute to a search for career alternatives. These factors include boredom, reaching a structural plateau in jobs, lack of stability in the university 
administration, and overwork. The current tempo and demands on the director's job will not change soon, Woodsworth asserted, and the onus is on the individual library director to develop alternative career paths and escape routes. Woodsworth's article and conclusions inspired us to examine trends in contemporary ARL university library directorships and to analyze the changes among the group over a 20-year period (1970 to 1989).

\section{Purpose and Methodology}

No attempt was made to analyze the directorship of an institution before the library became an ARL member; therefore, the population of this study ranged from 75 university libraries in 1970 to 107 in 1989. One library, which was an ARL member in 1970 but not 1989, was excluded from the study. Statistical data on the number of volumes, volumes added, materials expenditures, total expenditures, and number of staff for each library were extracted from the annual ARL Statistics.

Throughout this study, the title "director" is used to denote the top executive of an ARL library, regardless of the exact title. The latest ARL membership list was used to locate the name of the current director. ${ }^{10}$ Acting directors were excluded from this study; Canadian ARL library directors were included. Biographical directories were used to locate information about the date of appointment, previous position, and reason for leaving." ${ }^{.1}$ Directors who stepped down at age 60 were classified as retired if no other reason could be located. In order to check the trends noted by previous researchers for directors in the beginning of 1970 , the beginning of 1979 , and the end of 1989, a further search was made in biographical directories to locate information on age and highest degree held. ARL's Newsletter and issues of College \& Research Libraries News were examined for announcements of retirements, recent position changes, and months of appointment for newly hired directors. ${ }^{12}$ The American Library Directory was also used to verify the names of directors and years of service.

The gender of the director was considered the critical variable for analysis, and our personal knowledge was used to complete gender information not located elsewhere. Every effort was made to locate missing information for other variables. However, when we could not locate the director's age or other information in published sources, we did no personal follow-up to the individual or the director's library to supply the data. Uncollected data were treated as missing for all statistical analyses. The available data collected were coded, keyboarded, verified, and analyzed using the Statistical Package for the Social Sciences for personal computers (SPSS/PC+).

\section{FINDINGS: THE DIRECTORS}

\section{Gender and Area}

We began by looking at the distribution of directors by gender in seven geographical areas, as displayed in table $1 .{ }^{13}$ Of the 1,798 cases we observed, $1,538(85.5 \%)$ represented libraries with a male director, and $260(14.5 \%)$ represented libraries with a female director. Table 1 shows that male and female directors were fairly evenly distributed by geographic areas, ranging from a high of $23.8 \%$ in the Midwest for male directors to a high of $27.7 \%$ in the East for female directors. Major findings will be presented by years and gender for ARL directors. Because the Canadian ARL directors proved to be not significantly different from other areas on the key variable of gender, data on Canadian ARL libraries were analyzed along with data from the U.S. ARL libraries. Interesting characteristics peculiar to Canadian directors are reported as appropriate.

\section{Position Titles}

Although we have considered each top executive to be a director, we also were interested in changes in official titles used, as these might provide clues about the changing role or perception of libraries and librarians on research university campuses. Although the use of the title "director" has declined from 
TABLE 1

OBSERVATION BY GENDER AND AREA

\begin{tabular}{lrrrrrr}
\hline & \multicolumn{3}{c}{ Male Directors } & \multicolumn{2}{c}{ Demale } & \multicolumn{2}{c}{ Directors } & \multicolumn{1}{c}{ Totals } \\
& \multicolumn{1}{c}{$\#$} & \multicolumn{1}{c}{$\%$} & \multicolumn{1}{c}{$\#$} & \multicolumn{1}{c}{$\%$} & \multicolumn{1}{c}{$\#$} & \multicolumn{1}{c}{$\%$} \\
\hline East & 198 & 12.9 & 72 & 27.7 & 270 & 15.0 \\
Mid-Atlantic & 272 & 17.7 & 52 & 20.0 & 324 & 18.0 \\
South & 310 & 20.2 & 28 & 10.8 & 338 & 18.8 \\
Midwest & 366 & 23.8 & 20 & 7.7 & 386 & 21.5 \\
West (Mountain) & 113 & 7.3 & 4 & 1.5 & 117 & 6.5 \\
Pacific & 167 & 10.9 & 30 & 11.5 & 197 & 11.0 \\
Canada & 112 & 7.3 & 54 & 20.8 & 166 & 9.2 \\
$\quad$ Total & 1,538 & 100.0 & 260 & 100.0 & 1,798 & 100.0 \\
\hline
\end{tabular}

$65.3 \%$ of all directors in 1970 to $49.5 \%$ (51.4\% of the males and $45.5 \%$ of the females) in 1989, "director" is still the most common title used. "Librarian," with $29.9 \%$ in 1989 (28.3\% of the males and $33.3 \%$ of the females), and "dean," with $12.1 \%(13.5 \%$ of the males and $9.1 \%$ of the females), follow it.

These findings are consistent with those of Wong and Zubatsky in 1983 when $50.7 \%$ of the 75 male directors and $31.3 \%$ of the 16 female directors held the title "director"; $29.3 \%$ of the males and $18.8 \%$ of the females in 1983 used the title "librarian," and $13.3 \%$ of the males and $12.5 \%$ of the females were called "dean."14

\section{Gender Issues}

No contemporary discussion of the characteristics of ARL directors can fail to focus on the changes resulting from an increased number of female top executives in many professions and industries. Our analysis reveals that there has, indeed, been a significant increase in the number of female ARL directors, from none in 1970 to $32(31.7 \%$ of the 101 permanent directors) in 1989. Are any observable patterns attributed to this change?

Replacements. Recently, a colleague remarked in passing that it appeared that male directors are being replaced by females, and female directors are being replaced by males. We took up the challenge of verifying this casual observation and examined the rate of turnover as well as any significant patterns related to turnover. We also thought it important to confirm recent remarks by Woodsworth and others, who refer to observably shorter tenures for contemporary ARL directors.

Our analysis reveals that there has, indeed, been a significant increase in the number of female ARL directors, from none in 1970 to 32 in 1989.

Table 2 displays the gender of the newly hired director and the gender of the director replaced by the new hire, classified by time periods in 5-year intervals. The number of replacements has increased slightly over the past 20 years, from 45 in 1970-1974 to 50 in 1985-1989. Some may interpret these data to justify the contention that turnover is accelerating. However, we do not think that a growth from an average of 9 per year to 10 per year over a 20 -year period represents a significant increase. Time will tell if this is the start of a general trend.

Table 2 shows interesting data about the genders of new hires and the incumbents they replaced. In the period 1970 to 1974 , no males replaced female directors, but 4 females replaced males. By 1985 to $1989,54 \%$ of all new hires were of a gender different from the incumbent they replaced. Of the 50 replacements in this period, 8 males replaced female directors, and 19 females replaced male 
TABLE 2

NEW HIRES AND REPLACEMENTS BY PERIOD

\begin{tabular}{|c|c|c|c|c|c|c|c|c|}
\hline \multirow[t]{2}{*}{ 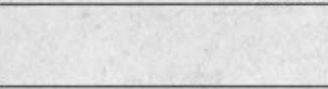 } & \multicolumn{2}{|c|}{$1970-74$} & \multicolumn{2}{|c|}{$1975-79$} & \multicolumn{2}{|c|}{$1980-84$} & \multicolumn{2}{|c|}{$1985-89$} \\
\hline & \# & $\%$ & \# & $\%$ & \# & $\%$ & \# & $\%$ \\
\hline Male replacing female & 0 & 0.0 & 3 & 7.0 & 2 & 5.0 & 8 & 16.0 \\
\hline Female replacing male & 4 & 8.9 & 7 & 16.3 & 9 & 22.5 & 19 & 38.0 \\
\hline Male replacing male & 41 & 91.1 & 33 & 76.7 & 26 & 65.0 & 19 & 38.0 \\
\hline Female replacing female & 0 & 0.0 & 0 & 0.0 & 3 & 7.5 & 4 & 8.0 \\
\hline Total & 45 & 100.0 & 43 & 100.0 & 40 & 100.0 & 50 & 100.0 \\
\hline
\end{tabular}

directors. The data tend to indicate that a female applicant has a better chance of being offered a position in an institution that previously had been directed by a male than by an institution that had a female director. Male applicants appear to have an equal chance of replacing a male or a female.

The data indicate that a female applicant has a better chance of being offered a position in an institution that had previously been directed by a male than one that had a female director.

Tenure. We also looked at the tenure of each individual who stepped down from the directorship. In the period 1970 to 1974 , the average years of service for the male directors who left their positions were 12.8 years; there were no female directors replaced during that time period. From 1975 to 1979 , the average years of service for male directors leaving their positions was 10.3 years; female directors being replaced had served an average of 4 years. During 1980 to 1984 , the average years of service for replaced directors were as follows: male directors, 10.2 and female directors, 5.8 . There continued to be a significant difference between the tenure of departing male and female directors in 1985 to 1989 , when departing male directors averaged 11.7 years of service in contrast to replaced female directors, who averaged 6.5 years of service. The average tenure of the directors who left their positions has de- clined slightly for male directors over the last two decades, from 12.8 years in 1970 to 1974 to 11.7 years in 1985 to 1989. The average for all directors replaced was 10.3 in 1985 to 1989 , compared with 12.8 in 1970 to 1974.

Table 3 details the tenure of incumbent directors for 1970 through 1989 in 5-year intervals. Three ARL libraries were under the leadership of the same male director for the entire 20-year period covered by this study. Because female directors are newer to directorships as a group, it was expected that they would average fewer years in their positions. The 11 female directors observed in 1979 had an average of 4 years in their positions. By 1989, the average number of years for 30 female directors had increased to 5.2 years. Male directors have shown a decline in the number of years in the position, from 10.3 years in 1970 to 8 years in 1989 . The average tenure for all incumbents in 1989 was 7.1 years. The inclusion of Canadian directors in this study had little influence on the tenure variable. When Canadian librarians were excluded, the average tenure fell by only $.01 \%$. The results of this study show that the male directors, at least, exceed the average 5 or 6 years of service that McAnally and Downs predicted, although it must be noted that the trend appears to be toward shorter tenures. ${ }^{15}$ The difference between the average tenure of replaced directors and the tenure of the incumbents indicates that directors are staying in their positions for shorter lengths of time.

Turnover. In 1989,10 positions, or $9.3 \%$ of the 107 directorships, were vacated. To put this into perspective, we looked at similar data in another profession. Turnover 
TABLE 3

TENURE OF INCUMBENT DIRECTORS

\begin{tabular}{lrrrrrrr}
\hline & \multicolumn{3}{c}{ Gender } & \multicolumn{2}{c}{ Total } \\
\cline { 2 - 6 } Year & \multicolumn{2}{c}{ Male } & \multicolumn{2}{c}{ Female } & & \multicolumn{1}{c}{ Avg. } \\
\hline 1970 & 72 & Avg. & $\#$ & Avg. & \# & Avg \\
1974 & 73 & 7.5 & 4 & 2.3 & 77 & 7.3 \\
1979 & 78 & 7.2 & 11 & 4.0 & 89 & 6.8 \\
1984 & 81 & 8.5 & 20 & 4.7 & 101 & 7.7 \\
1989 & 71 & 8.0 & 30 & 5.2 & 101 & 7.1 \\
\hline
\end{tabular}

rates among $\mathrm{ARL}$ directorships compare favorably with a recently reported study that showed the average turnover rate for the chief executive officers of Utah hospitals to be $16.6 \% .^{16} \mathrm{~A}$ fruitful area for future study is how the turnover rate and the reasons for turnover compare between library executives and executives in other fields. Richard B. Dwore and Bruce P. Murray found that a minority of turnovers were due to involuntary reasons. ${ }^{17}$ The highest percentage of turnovers ( $44 \%$ ) were attributable to voluntary reasons, such as promotion. Glenn M. McEvoy and Wayne F. Cascio also found evidence that turnover is lower among good performers. ${ }^{18}$ Reasons for ARL directors leaving will be discussed below.

\section{Reasons for Departing}

Why do directors leave their posts? Has this changed over time? Do career patterns include movement from one ARL directorship to another? Table 4 shows the directors' reasons for leaving their positions. Throughout the four time periods shown, the most frequent reason for male directors' leaving was retirement. The percentage of male director retirements was fairly consistent, ranging from a low of $47.4 \%$ of all reasons for leaving in 19751979 to a high of $59.3 \%$ of all reasons for leaving in 1980-1984. The pattern is less clear for female directors because we could observe a reason for leaving for only 17 females during the entire 20 years under study. Across all time periods, 5 of the 17 female directors $(29.4 \%)$ left for directorships in other ARL libraries, 4 (23.5\%) retired, $4(23.5 \%)$ went into teaching, 2
(11.8\%) took positions in other academic libraries, and $2(11.8 \%)$ left for jobs outside academia.

Another frequent reason for leaving was to assume a directorship at another ARL university library. The percentages of individuals choosing this course of action ranged from $23.7 \%$ of the male directors in 1975 1979 to $37.5 \%$ of the female directors in 1980 1984. These large percentages may reflect the fact that directors are looking for opportunities to direct libraries with greater resources or in different settings, or to revitalize themselves while staying within a directorship, or to compensate for the lack of alternative positions within their institutions. Although upward mobility beyond the directorship is uncommon, some individuals do find career opportunities in their own institutions. In 1970 to 1974 , no director left toaccept another position in the same institution or library, and only one accepted a nonlibrary, nonuniversity position elsewhere. By 1985 to $1989,16 \%$ of the male directors who left during that period, in fact, accepted other positions in their own institutions. Also, the number who leave for nonlibrary, nonuniversity positions is increasing. These nonlibrary positions included such posts as the executive director of a government entity and the presidency of a private, nonprofit organization. In 1985-1989, $4 \%$ of the male directors and $28.6 \%$ of the female directors moved into nonlibrary positions.

In the period 1970-1974, the highest number of observations where a reason for leaving was known (44 male directors) was observed. No female director, for whom we could identify a reason for leaving, departed from a permanent directorship during this 
ARL Directors

period. In 1970 to 1974,10 (22.7\%) of the male directors leaving went into teaching; by 1985 to 1989 this reason had declined to $3(12 \%)$ of the males and 1 $(14.3 \%)$ of the females. Teaching has apparently become a less attractive alternative. Also, the large portion of the directors who do not have doctorates may not find this to be a viable option.

Cohn, in studying the ARL directors from 1933-1973, also found the most frequent reason for leaving to be retirement or death. ${ }^{19}$ His data revealed a decline from $78 \%$ in 1933 , to $45 \%$ in $1934-1969$ to $33 \%$ in $1970-1973$. He found that the second most frequent reason for leaving was to go to another library, followed by entry into teaching. Cohn found that none left to go to another ARL library in 1933; $11 \%$ went to another ARL library in 19341969 , and $8 \%$ in $1970-1973$. Although the general results of our study are consistent with Cohn's findings, more directors now seem to be leaving for positions in other ARL libraries than ever before. Obviously, current ARL directors of smaller institutions are likely candidates for directors of larger institutions; however, some of these changes may be perceived as lateral moves, which perhaps indicates the need of today's directors for revitalization.

In looking at this component of the study, we realize that the official reasons given for leaving might not always tell the real story. However, our only other source of information about reasons for leaving is purely anecdotal. Because such information is highly inaccurate, unreliable, and not verifiable, we have chosen to analyze only the official reasons for leaving.

\section{Previous Position}

What route have ARL directors taken to reach their positions? Although examining this question in detail is much too complex for the scope of this study, we did consider the positions individuals held immediately before assuming the directorship (see table 5). Most new directors come from associate directorships of other ARL libraries, from directorships of other ARL libraries, or from other positions within the

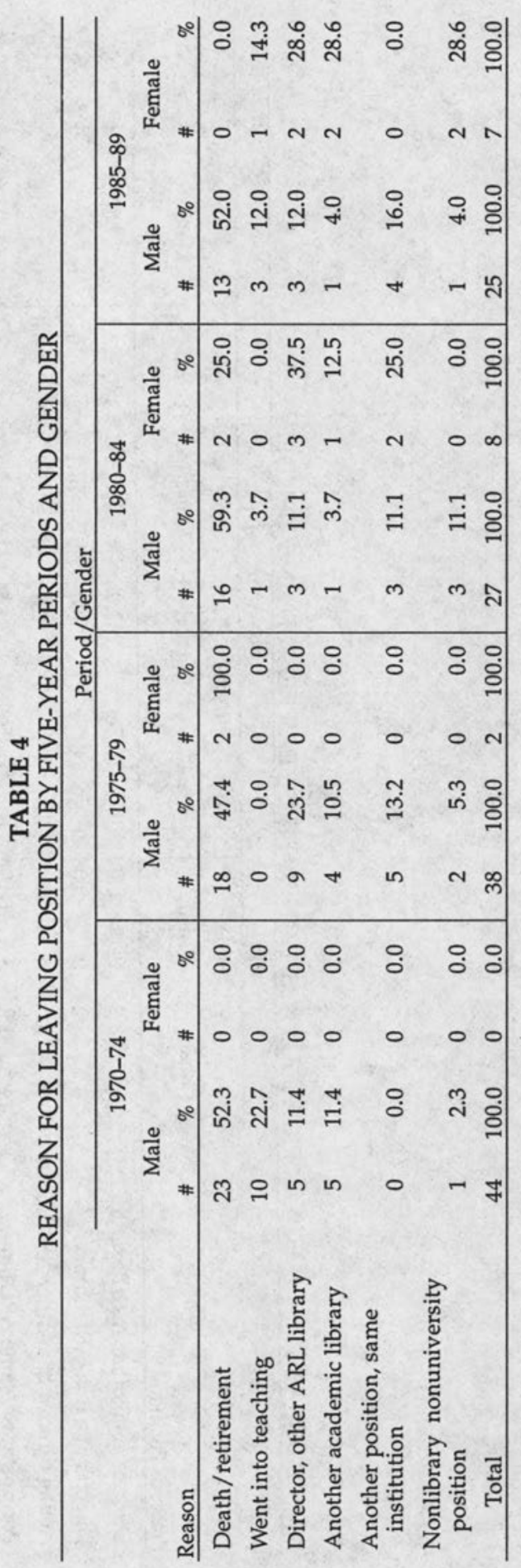


TABLE 5

PREVIOUS POSITION BY FIVE-YEAR PERIOD AND GENDER

\begin{tabular}{|c|c|c|c|c|c|c|c|c|c|c|c|c|c|c|c|c|}
\hline \multirow[b]{4}{*}{ Previous Position } & \multicolumn{16}{|c|}{ Period/Gender } \\
\hline & \multicolumn{4}{|c|}{$1970-74$} & \multicolumn{4}{|c|}{$1975-79$} & \multicolumn{4}{|c|}{$1980-84$} & \multicolumn{4}{|c|}{$1985-89$} \\
\hline & \multicolumn{2}{|c|}{ Male } & \multicolumn{2}{|c|}{ Female } & \multicolumn{2}{|c|}{ Male } & \multicolumn{2}{|c|}{ Female } & \multicolumn{2}{|c|}{ Male } & \multicolumn{2}{|c|}{ Female } & \multicolumn{2}{|c|}{ Male } & \multicolumn{2}{|c|}{ Female } \\
\hline & \# & $\%$ & \# & $\%$ & \# & $\%$ & $\#$ & $\%$ & \# & $\%$ & \# & $\%$ & \# & $\%$ & \# & $\%$ \\
\hline Director at another ARL library & 8 & 18.2 & 0 & 0.0 & 10 & 21.7 & 1 & 11.0 & 4 & 12.9 & 3 & 23.1 & 3 & 10.7 & 4 & 18.2 \\
\hline Director at a non-ARL library & 8 & 18.2 & 0 & 0.0 & 10 & 21.7 & 0 & 0.0 & 5 & 16.1 & 0 & 0.0 & 6 & 21.4 & 2 & 9.1 \\
\hline Acting director at another ARL library & 0 & 0.0 & 0 & 0.0 & 0 & 0.0 & 0 & 0.0 & 0 & 0.0 & 0 & 0.0 & 0 & 0.0 & 3 & 13.6 \\
\hline Position at the same ARL library & 14 & 31.8 & 3 & 100.0 & 6 & 13.0 & 3 & 33.3 & 11 & 35.5 & 1 & 7.7 & 6 & 21.4 & 5 & 22.7 \\
\hline $\begin{array}{l}\text { Associate director at another ARL } \\
\text { library }\end{array}$ & 8 & 18.2 & 0 & 0.0 & 9 & 19.6 & 5 & 55.6 & 8 & 25.8 & 6 & 46.2 & 9 & 32.1 & 5 & 22.7 \\
\hline Other position at another ARL library & 1 & 2.3 & 0 & 0.0 & 5 & 10.9 & 0 & 0.0 & 0 & 0.0 & 2 & 15.4 & 1 & 3.6 & 1 & 4.5 \\
\hline Other position at a non-ARL library & 1 & 2.3 & 0 & 0.0 & 3 & 6.5 & 0 & 0.0 & 0 & 0.0 & 1 & 7.7 & 0 & 0.0 & 0 & 0.0 \\
\hline From teaching & 3 & 6.8 & 0 & 0.0 & 2 & 4.3 & 0 & 0.0 & 2 & 6.5 & 0 & 0.0 & 3 & 10.7 & 1 & 4.5 \\
\hline Position in nonlibrary, nonuniversity & 1 & 2.3 & 0 & 0.0 & 1 & 2.2 & 0 & 0.0 & 1 & 3.2 & 0 & 0.0 & 0 & 0.0 & 1 & 4.5 \\
\hline Total & 44 & 100.0 & 3 & 100.0 & 46 & 100.0 & 9 & 100.0 & 31 & 100.0 & 13 & 100.0 & 28 & 100.0 & 22 & 100.0 \\
\hline
\end{tabular}


same institution. The pattern of previous positions is slightly different for male and female directors over time. The percentage of male directors coming from directorships at other ARL libraries declined from $18.2 \%$ in $1970-1974$ to $10.7 \%$ in 1985-1989, but there has been an increase in new male directors coming from the ranks of associate directors at other ARL libraries, from $18.2 \%$ of all new directors in 1970 1974 to $32.1 \%$ in $1985-1989$. There also has been a parallel decline in the percentage of males coming from the same institution and a slight increase in the number of new male directors coming from teaching. In $1985-1989,21.4 \%$ of male directors came from directorships at non-ARL libraries.

In contrast, only $9.1 \%$ of the female directors held a directorship in a non-ARL library before their present positions. The most frequent sources of female directors appear to be positions at the same ARL institution and associate directorships at other ARL libraries. This is consistent with the recent emergence of female directors in the field. However, increasing numbers of them are changing positions, and $18.2 \%$ of the female directorships assumed in 19851989 were by persons already directing ARL libraries. This is much higher than the proportion of male directors moving among ARL directorships (10.7\%). In 19851989 , no male directors, but $13.6 \%$ of the new female directors, came from acting directorships of other ARL libraries. Three acting female directors in the East assumed permanent positions in the South. All three previously had been associate directors in the institutions that had acting directorships. Cohn indicated that despite the fact that mobility is often the key to success, females could reach the directorship only by "staying put and 'proving' their abilities to those making appointments. ${ }^{\prime 20}$ Fortunately, it appears that other career paths have opened up for female directors since Cohn made his observations in 1976.

\section{Highest Degree}

Many advertisements for library directors indicate a preference for doctoral-level training. Has this requirement resulted in the current directors holding higher degrees than previous directors? The doc- toral degree in library science or a subject field was the highest degree held by $38.3 \%$ of the directors in $1989(43.3 \%$ of the male directors and $25.9 \%$ of the female directors). The possession of a library science or subject doctorate has declined from $43.9 \%$ held by male directors in 1970 . As this decline indicates, male directors are generally more likely than female directors to hold the doctorate. Over the past 20 years, males were also more likely to hold a second master's degree (see table 6). However, by 1989 , the numbers for male and female directors were virtually the same $(22 \%)$. There has been a decline in directors who hold only the bachelor of library science, from $6.1 \%$ of the male directors in 1970 to $3 \%$ in 1989.

Wong and Zubatsky studied degrees, but did not specify the highest degree. ${ }^{21}$ Karr, who studied highest degree held, but did not distinguish between the degrees held by male and female directors, found that most directors obtained additional academic degrees and that the proportion of doctorates fell from nearly half in 1966 to one-third in $1981 .^{22}$ The second master's degree had apparently become an acceptable substitute for the doctorate. Those results are consistent with the results of our study. Karr also found that, in 1966, 15\% of all directors lacked library degrees, but that by 1981 all directors were graduates of a library program. ${ }^{23} \mathrm{How}$ ever, our data show that this trend has not continued. As indicated in table 6, in 1970, $6.1 \%$ of the directors had a Ph.D. and no M.L.S., and $3 \%$ had a subject master's degree and no library credentials. By 1989, the percentages had not changed appreciably. Of themale directors, one $(1.5 \%)$ had the subject master's and no library education credentials; $7.5 \%$ had a subject Ph.D. and no M.L.S. Of the female directors in 1989 , one $(3.7 \%)$ had the subject master's degree and no M.L.S. Apparently, those making the appointments in ARL research university libraries still do not consider it imperative that candidates have library science educational credentials.

Age

The average age of male directors has remained fairly consistent: 54.1 years in 1970, 52.3 years in 1979, and 54.2 years 


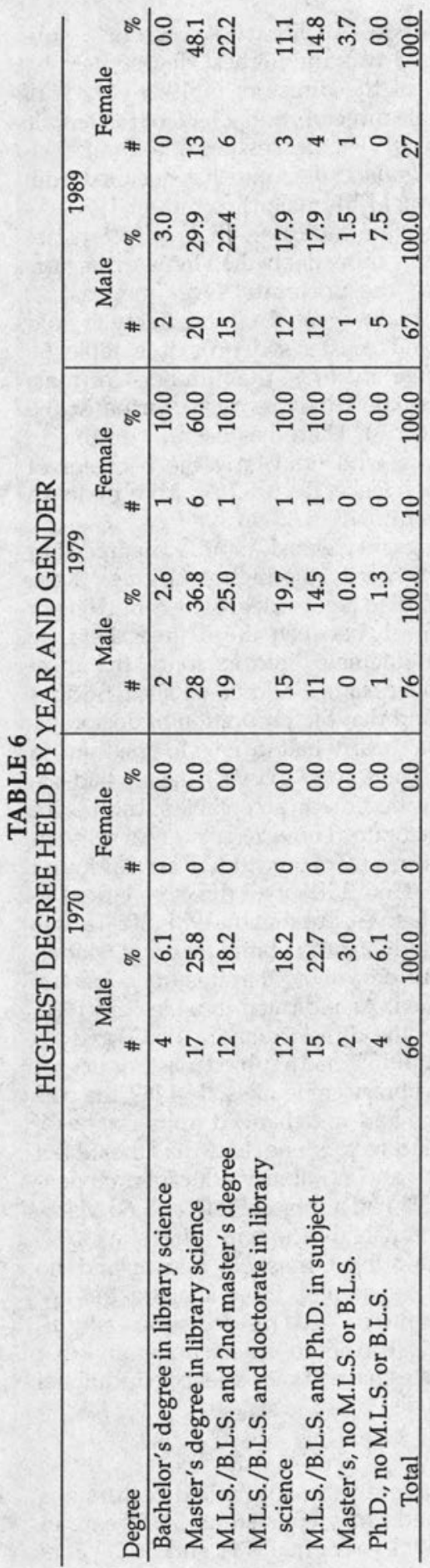

in 1989. Female directors as a group are younger than their male counterparts. There were none in 1970; in 1979, they had an average age of 47.9 years and in 1989 , an average age of 50.9 years. The inclusion of Canadian directors had little influence on the average age. For example, when Canadian directors are excluded, the average age in 1989 for male directors was 54.7 and 51 for female directors. Previous studies have found that the director was generally in the early 50 s.

It appears that other career paths have opened up for female directors since Cohn made his observations in 1976.

While the difference in ages between male and female directors was significant, the results should be viewed with some caution. Some current biographical directories do not list ages, and we could not locate the birth dates of many of the newer directors (both male and female). We think that the actual ages are probably somewhat younger than those found, even though the results of this study are consistent with the results of previous studies. For example, we could locate ages for only 86 of the 101 permanent directors in 1989 . Of the remaining 15 directors, 6 were females and 3 were males, whom we believe are in their 40 s.

\section{FINDINGS: THE LIBRARIES}

In 1970, the 75 ARL libraries included in this study contained a total of 136 million volumes, with an average of 1.8 million volumes and 242 staff per library. By 1989 , the membership had grown to 107 libraries. The 106 libraries that completed the 1989 ARL statistics survey held 295 million volumes, with an average of 2.8 million volumes and 322 staff per library. During the tremendous growth of the past two decades, have changes in library size affected the relationship between library directors and libraries?

This study collected selected descriptive statistics about ARL libraries-statistics that might also relate to the characteristics 
of the library directors. The statistics included the number of volumes in the collection, gross number of volumes added to the collection, materials and binding expenditures, and total operating expenditures. Two additional variables were calculated on materials and binding expenditures and on total operating expenditures. These variables showed the increase in expenditures from the previous year so that percentage increases in expenditures could be separately analyzed. We thought that these change variables were likely to be the descriptive variables first influenced by a change in directors.

For 1989 and the population as a whole, no significant differences were found for the various descriptive statistics analyzed by the geographic areas classified for this study. For example, in 1989, the average number of volumes in the libraries ranged as follows: 3.3 million, East; 2.9 million, Mid-Atlantic; 2.3 million, South; 3.2 million, Midwest; 3 million, Pacific Coast; 2.2 million, Canada; and 2.1 million, West (Mountain Standard Time).

While there were some differences among the descriptive variables and gender, these were slight. Table 7 shows the average descriptive statistics by gender for 1989. The 70 male directors controlled a slightly higher average number of volumes, volumes added, and total expenditures than the 30 female directors. Female directors in 1989 had control over a slightly

TABLE 7

DESCRIPTIVE STATISTICS AVERAGES BY GENDER FOR 1989

\begin{tabular}{lrr}
\hline & \multicolumn{2}{c}{ Gender } \\
\cline { 2 - 3 } & $\begin{array}{c}\text { Male } \\
\text { Directors } \\
(\mathrm{N}=70)\end{array}$ & $\begin{array}{c}\text { Female } \\
\text { Directors } \\
(\mathrm{N}=30)\end{array}$ \\
\hline $\begin{array}{l}\text { Volutistics } \\
\text { library }\end{array}$ & $2,830,581$ & $2,568,562$ \\
$\begin{array}{l}\text { Volumes added } \\
\text { Total staff }\end{array}$ & 81,096 & 74,824 \\
$\begin{array}{l}\text { Material } \\
\text { expenditures }\end{array}$ & $\$ 3,901,315$ & $\$ 4,048,114$ \\
$\begin{array}{c}\text { Total } \\
\text { expenditures }\end{array}$ & $\$ 5,963,470$ & $\$ 5,647,779$ \\
\hline
\end{tabular}

higher average expenditure for materials and a larger average staff. In 1970, there were no female directors for comparison on the descriptive statistics. In 1979, there were 11 female directors and 78 male directors. In that year, the male directors controlled a slightly higher average number of all the descriptive statistics, from volumes ( 2.3 million versus 1.9 million) to staff (304 versus 289 ).

\section{Female directors have increased their control over resources in the past two decades.}

Although the male directors generally control larger resources than their female counterparts, the differences are slight, and female directors have increased their control over resources in the past two decades as indicated by the selected descriptive statistics. In fact, male and female directors were fairly well matched in 1989 on two important variables: volumes in the collection and total expenditures. $\mathrm{Li}$ braries with more than 3 million volumes in 1989 were controlled by $27.1 \%$ of the male directors and $23.3 \%$ of the female directors. Fifty percent of the male directors controlled libraries with more than $\$ 10$ million in expenditures; $53.3 \%$ of the female directors' libraries had more than $\$ 10$ million in expenditures. Those figures indicate that there has been considerable progress for female directors since 1970, when they were not even represented among ARL directors.

\section{Expenditures}

Table 8 details the percentage change in materials expenditures and total expenditures related to a change in directorship by gender. When the percentage expenditure variables were controlled by gender and analyzed for a change or no change in directorship, the male directors' averages on the two percentage increase variables were lower if a new hire had occurred than the female directors'. When controlled for gender and new hires, the average percentage of change in total expenditures was $8.5 \%$ 
TABLE 8

AVERAGE PERCENTAGE INCREASE OF MATERIALS AND TOTAL EXPENDITURES BY GENDER AND CHANGE IN DIRECTORS

Gender

\begin{tabular}{cccccccccc} 
& \multicolumn{3}{c}{ Male Directors } & \multicolumn{4}{c}{ Female Directors } \\
& \multicolumn{2}{c}{ Change } & \multicolumn{2}{c}{ No Change } & \multicolumn{2}{c}{ Change } & \multicolumn{2}{c}{ No Change } \\
Expenditures & $\#$ & $\%$ & $\#$ & $\%$ & $\#$ & $\%$ & $\#$ & $\%$ \\
\hline Materials & 132 & 8.8 & 1,290 & 8.8 & 45 & 11.3 & 209 & 9.1 \\
Total & 132 & 8.5 & 1,290 & 8.6 & 45 & 10.0 & 208 & 8.6 \\
\hline
\end{tabular}

for male directors and $10 \%$ for female directors. The materials expenditures percentage increase during change was $8.8 \%$ for male directors and $11.3 \%$ for female directors. In contrast to male directors, female directors apparently achieve a greater percentage increase in their budgets during their first year, as measured by percentage increase in materials expenditures and total expenditures. These increases might reflect part of the recruitment packages used to attract female directors, who apparently are in demand more than ever. In fact, as documented by the ARL Annual Salary Survey for the past three years, female directors earned an average salary higher than the average salary of male directors. ${ }^{24}$ However, we are reluctant to draw conclusions from this observation because the factors relating to budget changes are complex.

\section{Tenure and the Descriptive Variables}

To investigate further the relationship between tenure and the descriptive variables, we used stepwise multiple regression analysis. Tenure was the dependent variable, and the independent variables included gender of the directors, volumes, volumes added, materials expenditures, total expenditures, percentage change in materials expenditures, and percentage change in total expenditures. For 1970 and 1979 , no variables entered the equation using the .05 level of significance. For 1989 , gender entered the equation first (Multiple $\mathrm{R}=.23$ ), followed by percentage change in materials expenditures (Multiple $\mathrm{R}=.31$ ). No other variable entered the equation at the .05 level of significance. Gender of the director and percentage change in materials expenditures account for very little of the variation in tenure ( $\mathrm{R}$ Squared $=.09$ ).
While there is some relationship between gender, materials expenditures, and tenure, other factors outside the scope of this study apparently account for the length of tenure of library directors.

\section{CONCLUSIONS}

In examining the data about ARL directors over the past two decades, it is apparent that the most significant change has been the large increase in the number of female directors. Their ranks have grown from a handful in the 1970 s to nearly $30 \%$ of the total number of library directors in the late 1980s. Female directors are younger, have fewer years of service, and are not quite as educated as their male counterparts. Although there were no female ARL directors in 1970-and, in fact, very few during much of that decade-today, the resources controlled by both genders are fairly evenly matched. We find it most interesting that the average salary of female ARL directors now exceeds that of male ARL directors, and we also find it interesting that this fact has gone largely unnoticed. Therefore, even though there are still many fewer female than male directors, the data indicate that females have, by and large, achieved parity with their male counterparts, at least in terms of salaries and average resources controlled.

It is tempting to speculate about the apparently faster rise of females to ARL directorships and whether it has resulted from the influence of the women's movement, affirmative action pressures, qualitative differences in capabilities, or intense mentoring, to name only a few possible reasons. However, any conclusions we could draw at this point would be purely speculative and without basis in any solid research. We leave it to other researchers 
to investigate this complex yet important subject.

In the last five years, more than $50 \%$ of all new positions were filled by male directors replacing females or female directors replacing males. This interesting trend has implications for job hunters. We would expect this phenomenon to decrease and eventually disappear as more females are recognized to be viable candidates for directorships. We think it fair to predict that, judging from the last two decades, we will enter the twentyfirst century with more female directors than ever before.

Another important measure of parity will be that of average tenure. Our study is necessarily inconclusive on that point, primarily because female directors are still relatively new to their positions. Data in the future will be most interesting. Earlier studies, as well as at least one recent commentator, predicted that the average tenure of all directors would fall to about 5 or 6 years. Our study showed that, overall, the average tenure was 7.1 years in 1989. From 1985 to 1989 , departing male directors logged an average of 11.7 years of service in contrast to departing female directors, who averaged 6.5 years of service. Turnover rates (i.e., the number of directorships vacated) during the four 5-year periods under study remained fairly constant.

Research libraries are growing ever more complex, and it appears as if they will be under increasingly strong financial pressures in the 1990s, as higher education tries to deal with declining enrollments and skyrocketing costs. Previous authors, however, have pointed to similar factors in the past as the basis for both their observations about shortened tenureand their predictions of even shorter terms of service. Putting this all in perspective, we expect that studies done toward the end of the next decade will not show a significant drop in the length of service of the average ARL director, male or female.

This study confirmed many findings of previous studies of ARL directors. A typical director is still male, in his $50 \mathrm{~s}$, and with a doctorate degree. Before assuming his current directorship, he was likely an associate director at another ARL library. He probably will stay in an ARL directorship until he retires. But, among the emerging trends we identified is the growing tendency for ARL directors to move from one ARL directorship to another; therefore, the future typical director may end his career after stints as director of more than one ARL library.

We live in a society in which retirement ages are either increasing or becoming purely voluntary, and given that fact, we would ordinarily expect to see ARL directors retiring at later ages or after longer tenures. In much of the professional academic work force, administrators move among levels of responsibility for widely varying operations and frequently return to teaching positions well before the official end of their professional working lives, without stigmas of failure. Directors of ARL libraries, as Woodsworth pointed out, have very few and limited career options. Teaching is usually limited to persons with doctorates, and returning to such positions as reference librarian or cataloger is often impossible without a considerable amount of retraining and loss of face. Librarians are often perceived by universities to be inappropriate or unqualified for general administrative positions, and the number of nonprofit or nonlibrary institutions for which librarians are seen to be qualified is also very small. We frequently hear of directors who are burned out or who have become ineffective within their institutions. Yet, their options are indeed limited. Until the profession finds alternative career paths for ARL directors, we will continue to see them hanging on in their current positions (with average tenure rates remaining fairly stable or even increasing) or leaving the profession entirely. The first alternative leaves us with little opportunity to bring vitality and creativity to the leadership of our institutions. The second represents a major loss of talent and contributions to our libraries. 


\section{REFERENCES AND NOTES}

1. Arthur M. McAnally and Robert B. Downs, "The Changing Role of Directors of University Libraries," College \& Research Libraries 34:103-25 (Mar. 1973).

2. Anne Woodsworth, "Getting off the Library Merry-Go-Round: McAnally and Downs Revisited," Library Journal 114:35-38 (May 1, 1989).

3. William L. Cohn, "An Overview of ARL Directors, 1933-1973," College E Research Libraries 37:137-44 (Mar. 1976).

4. Jerry L. Parsons, "Characteristics of Research Library Directors, 1958 and 1973," Wilson Library Bulletin 50:613-17 (Apr. 1976).

5. Louis Kaplan, "Letter to the Editor: Directors of University Libraries," College $\mathcal{E}$ Research Libraries 38:521 (Nov. 1977).

6. Janice Clinedinst Fennell, "A Career Profile of Women Directors of the Largest Academic Libraries in the United States: An Analysis and Description of Determinants" (Ph.D. diss., Florida State Univ., 1978).

7. Ronald Dale Karr, "The Changing Profile of University Library Directors, 1966-1981," College \& Research Libraries 45:282-86 (July 1984).

8. William S. Wong and David S. Zubatsky, "Research Notes: The Tenure Rate of University Library Directors: A 1983 Survey," College E Research Libraries 46:69-77 (Jan. 1985).

9. Anne Woodsworth, "Getting off the Library Merry Go Round," 35-38.

10. Association of Research Libraries, Minutes (Washington, D.C.: ARL, 1969-1988). The membership list (including the name of the director) is given as an appendix in the minutes and also issued as a separate mailing to each member library.

11. Dorothy Ethlyn Cole, ed., Who's Who in Library Service (New York: Grolier Society, 1955); Lee Ash, ed., Who's Who in Library Service (Hamden, Conn.: Shoe String, 1966); Joel M. Lee, ed., Who's Who in Library and Information Services (Chicago: American Library Assn., 1982); Directory of Library and Information Professionals, published in collaboration with the American Library Assn. (Woodbridge, Conn.: Research Publications, 1988); directors not found in the library science directories were searched in the following: Who's Who in America 1970-71 (Chicago: Marquis Who's Who, 1970); Who's Who in America 1988-89 (Wilmette, Ill.: Marquis Who's Who, 1988).

12. The people/profile section of issues of College \& Research Libraries News was examined from January 1969 to February 1990 for major items on people in the news; because they are just lists of announcements, the long lists of appointments were not examined in detail.

13. The states were classified into the following areas: East-Connecticut, Delaware, Maryland, Massachusetts, New Hampshire, Rhode Island, Washington, D.C.; Mid-Atlantic-New Jersey, New York, Ohio, Pennsylvania; South-Alabama, Florida, Georgia, Kentucky, Louisiana, North Carolina, South Carolina, Tennessee, Texas, Virginia; Midwest-Illinois, Indiana, Iowa, Kansas, Michigan, Minnesota, Missouri, Nebraska, Oklahoma, Wisconsin; West (Mountain Standard Time)-Arizona, Colorado, New Mexico, Utah; Pacific Coast-California, Hawaii, Oregon, Washington; Canada.

14. Wong and Zubatsky, "The Tenure Rate," p.71.

15. McAnally and Downs, "The Changing Role," p.307.

16. Richard B. Dwore and Bruce P. Murray, "Turnover at the Top: Utah Hospital CEOs in a Turbulent Era," Hospital \& Health Services Administration 34:333-51 (Fall 1989).

17. Ibid.

18. Glenn M. McEvoy and Wayne F. Cascio, "Do Good or Poor Performers Leave? A Meta-Analysis of the Relationship between Performance and Turnover," Academy of Management Journal 30:744-62 (Dec. 1987).

19. Cohn, "An Overview of ARL Directors, 1933-1973," p.143.

20. Ibid., p.143-44.

21. Wong and Zubatsky, "The Tenure Rate," p.75.

22. Karr, "The Changing Profile," p.283-84.

23. Ibid., p.283.

24. Association of Research Libraries, ARL Annual Salary Survey (Washington, D.C.: ARL, $1987,1988,1989)$. 


\section{Build Your Future with ABRI}

\section{The library association that}

- contributes to the total professional development of over 10,000 academic and research librarians

- improves service capabilities of academic and research librarians

- promotes and speaks for the interests of academic and research librarianship

- promotes study and research relevant to academic and research librarianship

Membership benefits include free subscriptions to College \& Research Libraries. ACRL's official journal, and College and Research Libraries News. ACRL's news magazine for the profession - a $\$ 50$ value; reduced rates for conference registration and continuing education courses, discounts on ACRL publications - and much more.

The Association of College and Research Libraries is a division of the American Library Association (ALA). ALA membership is prerequisite to ACRL membership.

- I

Please rush information about joining ACRL to:

I Name

Address

City

State

Zip

Mail to: Association of College and Research Libraries a American

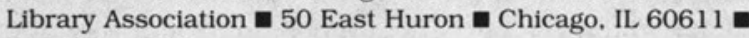

312/944-6780
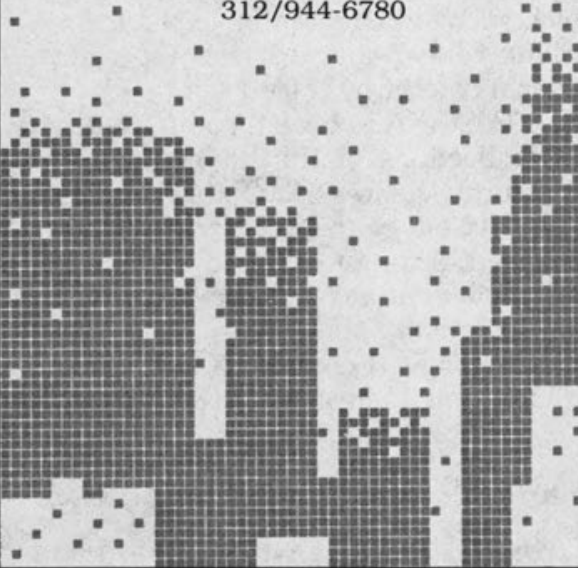

$=$ 